L.J. Maleong, (1991). Metodologi Penelitian Kualitatif, Bandung: Remaja Rosdakarya.

Miles, M.B. \& A.M. Huberman, (1992). Qualitative Data Analysis: A Sourcebook of New Methods, Beverly Hills : SAGE.

Mochtar Bukhori, (1993). Riset Partisipatoris Riset Pembebasan, Jakarta: Gramedia.

Varma, S.P.(1982), Teori Politik Modern, Jakarta, Rajawali Press.

Data Arsip Dusun Potorono 2010

Data dari Biro Pusat Statistik Kabupaten Bantul 2010.

\section{IMPLEMENTASI KONVENSI ANTI DISKRIMINASI PEREMPUAN DALAM POLITIK HUKUM INDONESIA}

Oleh:

Halili

\section{Universitas Negeri Yogyakarta}

Email: halili@uny.ac.id

\begin{abstract}
Abstrak
Penelitian ini bertujuan untuk mengkaji implementasi Konvensi Anti Diskriminasi terhadap Perempuan (Convention on the Elimination of all forms of Discrimination Against Women/CEDAW) dalam politik hukum Indonesia pada umumnya. Selain itu, juga untuk mengkaji kelemahankelemahan dalam politik hukum Indonesia yang terkait dengan perlindungan terhadap perempuan sebagaimana digariskan dalam Konvensi tersebut.

Penelitian ini merupakan studi literer yang ditulis dengan menggunakan pendekatan kualitatif-deskriptif. Sumber data penelitian ini adalah jenis paper. Teknik pengumpulan data yang digunakan adalah studi literature dan dokumentasi. Instrumen penelitian ini adalah peneliti sendiri dengan bantuan chek list dan recording note. Check list dan recording note tersebut digunakan untuk melacak dan merekam data yang dihasilkan melalui studi literatur dan dokumentasi. Pengujian keabsahan data menggunakan triangulasi. Langkah-langkah analisis yang digunakan dalam penelitian ini adalah analisis data kualitatif, meliputi reduksi data, display data, kesimpulan dan verifikasi.

Hasil penelitian ini menunjukkan: 1) Konvensi Anti Diskriminasi Perempuan tersebut sudah mulai dilaksanakan secara parsial melalui beberapa peraturan perundang-undangan, antara lain UU Kesehatan, UU Pemberantasan Tindak Pidana Perdagangan Orang, UU Paket Politik yang terdiri dari UU Pemilihan Umum DPR, DPD, dan DPRD, UU Pemilihan Presiden, UU Partai Politik, dan UU Penyelenggara Pemilihan Umum). 2) Implementasi Konvensi tersebut berimplikasi pada dua kecenderungan. Pertama, munculnya kecenderungan politik afirmatif bagi perempuan dalam berbagai bidang. Perempuan ditempatkan sebagai identitas yang membutuhkan pengakuan khusus atau istimewa secara formal dibandingkan dengan laki-laki. Kedua, mencoloknya warna aliran hukum feminis dalam hukum positif. Hukum positif merupakan turunan
\end{abstract}


dari filsafat positivism hukum (legal positivism) yang mendoktrinkan netralitas dan objektivitas hukum demi terciptanya kepastian hukum. Dengan implementasi Konvensi tersebut, sangat menonjol warna hukum yang berpihak pada perbendaan gender sebagaimana didoktrinkan oleh aliran hukum feminis. 3) Implementasi Konvensi tersebut dalam Politik Hukum Indonesia masih mengandung beberapa kelemahan fundamental, antara lain pada aspek materi hukum, dari aspek aparat penegak hukum serta sistem penghukumannya.

Kata Kunci: Konvensi Anti Diskriminasi terhadap Perempuan, CEDAW, Politik Hukum Indonesia, Aliran Hukum Feminis, Positivisme Hukum

\section{PENDAHULUAN}

Diskriminasi terhadap perempuan merupakan fenomena yang marak, baik di ruang-ruang publik (public space) maupun di aras rumah tangga (domestic space), terutama dalam bentuk kekerasan. Berbagai fakta kekerasan terhadap perempuan di Indonesia terjadi sedemikian rupa, misalnya, kekerasan fisik, seksual dan psikologis yang terjadi di dalam keluarga. Contoh konkrit yang terjadi antara lain: suami membentak istri, suami main serong, suami tidak memberikan uang belanja, dan lain sebagainya.

Di samping itu, kekerasan fisik, seksual, dan psikologis juga dialami oleh perempuan di kalangan masyarakat luas. Dalam banyak studi, sebagaimana juga seringkali diberitakan oleh media massa, perkosaan terhadap perempuan bahkan dalam angkutan umum masih sering terjadi. Pencabulan terhadap mereka juga mengalami peningkatan.

Bahkan, perempuan juga mengalami kekerasan secara fisik, seksual dan psikologis yang dilakukan atau dibenarkan oleh negara. Dalam sebuah studi yang dilakukan di daerah Banjarnegara, Jawa Tengah yang melibatkan 10 desa yang tersebar di 3 kecamatan ditemukan adanya bentuk kekerasan yang dilakukan oleh pemerintah atau penyelenggara negara yaitu: (1) Diberlakukannya UU dan Peraturan yang bias jender, (2) Larangan bagi perempuan telah menikah untuk memiliki nomor pajak sendiri, (3) Minimnya 64 anggota legislatif perempuan di DPRD, (4) Minimnya pegawai perempuan dalam instansi pemerintah pada posisi strategis, sehingga berpengaruh terhadap kebijakan yang tidak responsif gender (Sodikin dalam Fatayat edisi II/April, 2002).

Dengan adanya berbagai diskriminasi terhadap perempuan yang tidak hanya dalam lingkungan keluarga tetapi di berbagai bidang khususnya politik jelas terlihat bahwa kedudukan perempuan masih dianggap sebagai second sex. Dalam situasi demikian hak-hak perempuan belum bisa sepenuhnya diterapkan. Secara realita bahwa dalam kehidupan sehari-hari diskriminasi yang luas dan kekerasan terhadap perempuan di semua bidang masih tetap terjadi, seperti tingginya angka perempuan yang buta aksara dan rendahnya angka partisipasi politik perempuan.

Diskriminasi terhadap perempuan merupakan bentuk pelanggaran terhadap Hak Asasi Manusia (HAM). Fakta kesenjangan serta diskriminasi terhadap perempuan memang terjadi. Menurut pengamatan aktivis pembela perempuan, kesenjangan ini disebabkan beberapa faktor. Yaitu adanya pengaruh tata nilai sosial budaya yang masih menganut paham patriarki, yaitu keberpihakan yang berlebihan kepada kaum lakilaki daripada perempuan, adanya produk hukum dan peraturan yang belum responsif gender serta adanya pemahaman ajaran agama yang mendudukkan posisi laki-laki lebih tinggi dari perempuan.

Kebebasan dan kemandirian perempuan diharapkan dapat mengeluarkan mereka dari persoalan yang selama ini menghimpit yakni kemiskinan, pendidikan yang rendah, kesehatan perempuan yang memprihatinkan, terjadinya kekerasan pada perempuan, perempuan menjadi korban trafficking dan lain-lain, yang memang sampai saat ini masih mewarnai kehidupan perempuan. Mantan Menteri Pemberdayaan Perempuan Mutia Hatta juga mencatat tantangan yang dihadapi perempuan adalah masih tingginya angka kematian ibu, tindak kekerasan dan pemerkosaan, dampak negatif 
globalisasi terhadap perdagangan perempuan dan anak-anak, serta pemenuhan hak sipil, politik dan ekonomi yang belum dinikmati (Kompas, 17 Juli 2007)

Dalam literatur kajian HAM, baik normatif maupun akademis, dikenal beberapa instrumen Hak Asasi Manusia yang semuanya dikelompokkan menjadi dua, internasional dan nasional. Instrumen HAM internasional secara umum berupa kovenan (covenant), konvensi (convention), pakta (pact), dan berbagai bentuk perjanjian internasional lainnya. Sedangkan instrumen HAM nasional pada pokoknya berupa peraturan perundangundangan suatu negara. Salah satu instrumen internasional Hak Asasi Manusia adalah CEDAW (Convention on Elimination of all forms of Discrimination Against Women) yang pendeknya disebut Konvensi Anti Diskriminasi terhadap Perempuan.

Konvensi Anti Diskriminasi terhadap Perempuan tidak bisa dilaksanakan secara optimal kalau tidak ada instrumen nasional Indonesia. Dalam melaksanakan perjanjian-perjanjian Internasional tersebut, Indonesia menganut prinsip primat hukum nasional dalam arti bahwa hukum nasional mempunyai kedudukan lebih tinggi daripada hukum Internasional. Dasar kewenangan presiden dalam pembuatan Perjanjian Internasional diatur dalam pasal 11 UndangUndang dasar 1945 mengatur tentang perjanjian Internasional. Dalam konteks demikian sangat diperlukan implementasi yang optimal berbagai instrumen internasional Hak Asasi Manusia, agar perlindungan dan penegakan hukumnya kuat.

Implementasi Konvensi Anti Diskriminasi terhadap Perempuan melalui Politik Hukum Indonesia merupakan salah satu faktor penting dalam melindungi perempuan dari berbagai bentuk diskriminasi dan kekerasan. Implementasi Konvensi Anti Diskriminasi terhadap Perempuan yang baik akan memberikan perlindungan hukum yang kuat untuk penanggulangan masalah kekerasan terhadap perempuan serta penghapusan segala bentuk kekerasan terhadap perempuan. Perempuan akan mendapatkan perlindungan hukum dari berbagai tindakan yang bersifat diskriminatif, bahkan dengan adanya perlindungan ini maka perempuan akan mendapatkan perlakuan yang sederajat, baik di ranah publik maupun domestik.

Melihat latar belakang diskriminasi yang terjadi dan urgensi hukum nasional bagi pemenuhan hak perempuan untuk bebas dari berbagai bentuk diskriminasi, perlu dilakukan sebuah penelitian terhadap politik hukum Indonesia, pada aspek akomodasi dan derivasi berbagai prinsip pokok yang terkandung dalam Konvensi Anti Diskriminasi terhadap Perempuan. Penelitian ini bermaksud menggali jawaban dari pertanyaan berikut: a) Bagaimana implementasi Konvensi Anti Diskriminasi terhadap Perempuan dalam politik hukum Indonesia? b) Apa saja kelemahan implementasi anti diskriminasi terhadap perempuan dalam politik hukum Indonesia?

\section{CARA PENELITIAN}

Penelitian ini merupakan studi literer yang ditulis dengan menggunakan pendekatan kualitatif-deskriptif. Penelitian kualitatif yang dimaksud adalah penelitian yang dilakukan secara intensif dan terperinci terhadap suatu organisme, lembaga, atau gejala tertentu melalui suatu pengamatan atau analisis untuk menghasilkan data deskriptif, yaitu data yang berupa kata-kata tertulis atau lisan dari orang, gejala atau perilaku yang diamati (Molleong, 1991: 3). Teknik pengumpulan data penelitian ini menggunakan studi literatur dan dokumentasi. Instrumen penelitian ini adalah peneliti sendiri dengan bantuan chek list dan recording note. Check list dan recording note tersebut digunakan untuk melacak dan merekam data yang dihasilkan melalui studi literatur dan dokumentasi. Pengujian keabsahan data menggunakan triangulasi, yaitu suatu teknik pemeriksaan keabsahan data yang memanfaatkan sesuatu yang lain di luar data, untuk melakukan pengecekan atau pembandingan terhadap data itu (Moleong, 2002: 
178). Teknik triangulasi yang digunakan adalah triangulasi sumber, yaitu dengan membandingkan dan mengecek balik derajat kepercayaan suatu informasi melalui waktu dan alat yang berbeda. Teknik analisis yang digunakan adalah analisis data induktif. Langkah-langkah analisis yang digunakan dalam penelitian ini adalah analisis data kualitatif, yang menurut Sayekti Pujosuwarno (1992 : 19), meliputi reduksi data, display data, kesimpulan dan verifikasi.

\section{PEMBAHASAN}

\section{Implikasi Konvensi Anti Diskriminasi terhadap Perempuan}

\section{dalam Politik Hukum Indonesia}

a. Politik Afirmasi bagi Perempuan

Apa yang bisa dimaknai dari potret implementasi Konvensi Anti Diskriminasi terhadap Perempuan tersebut? Kuat kesan adanya keberpihakan khusus bagi perempuan, atau yang biasa dikenal sebagai affirmative action.

Dari kaca mata para feminis, diskusi mengenai affirmative action sesungguhnya masih problematik. Regulasi dalam Paket UU Politik, misalnya, mengindikasikan tindakan dengan keberpihakan khusus (affirmative action) kepada perempuan karena jenis kelaminnya. Keberpihakan ini sesungguhnya masih menempatkan perempuan sebagai "the other", sebagai kelompok "different". Namun secara sederhana, tindakan tersebut dianggap positif karena mendorong perempuan untuk lebih "terbuka" dan mendesak sistem untuk memperlakukan kaum perempuan lebih sederajat dengan laki-laki.

Namun, bagi para anti-esensialis, hukum semacam itu yang memberikan ruang tertentu kepada perempuan berdasarkan jenis kelaminnya (apalagi dengan limitasi prosentase tertentu) tidak cukup memberikan keadilan bagi perempuan. Apalagi jika dikaitkan dengan pengalaman banyak perempuan yang beraneka ragam (heterogen).

Feminis yang lebih substantif, semacam Carol Smart, memandang hukum dengan affirmative action tidak akan banyak berpengaruh kepada keadilan perempuan dalam berbagai bidangnya. Penyeragaman persoalan perempuan sama problematiknya dengan diskriminasi atas perempuan itu sendiri. Konstruksi hukum yang diidealkan oleh pemikir seperti Cain, Finley, dan Smart dibangun atas pengalaman perempuan tidak bisa hanya dalam wajah kuota $30 \%$. Metode hermeunetika dalam hukum menjadi keharusan, meskipun sesungguhnya masalah partisipasi politik perempuan bukan semata-mata persoalan hukum, namun juga persoalan kultural. Ada banyak cultural barrier, antara lain realitas bahwa perempuan dalam masyarakat lebih mengidentifikasi dirinya sebagai "bukan dirinya seutuhnya" akan tetapi "bagian lain dari suaminya". Seorang perempuan bernama Linda, misalnya, istri dari seorang laki-laki bernama Totok akan diidentifikasi oleh komunitasnya atau bahkan mengidentifikasi diri sebagai "Bu Totok", bukan "Bu Linda". Kendala lain adalah ketidakpercayaan pada kepemimpinan perempuan, sebab agama dalam sebagian besar pemahaman masyarakat tidak mendapat otoritas (kewenangan) untuk kepemimpinan seperti laki-laki.

Bila yang diidealkan destruksi hukum-jalan yang ditawarkan oleh Smart-untuk keadilan komprehensif atas perempuan (dan laki-laki) tanpa terkungkung dengan jenis kelaminnya, jelas masih sangat jauh. Mereformasi UU warisan penjajah saja, seperti KUHP, belum mampu kita lakukan, apalagi jika secara komprehensif harus mendestruksi hukum bahkan di level cara pikir (mindset) konstruksi hukum. 
b. "Feminist Jurisprudence" dalam Politik Hukum Indonesia Doktrin positivisme hukum secara umum mendominasi politik hukum negara, oleh karena sifatnya yang sebangun dengan sifat regulasi yang dikeluarkan oleh Negara sebagai lembaga yang berwenang memaksa, mengikat dan mencakup semua (all-encompassing, allembracing) (Harold J. Laski, 1947: 8-9, Miriam Budiardjo, 1996: 40-41). Dominasi pemikiran positivisme hukumsebagai aliran filsafat hukum-dipengaruhi oleh latar belakang kontekstual (ruang dan waktu) pada abad 19, dimana sains (ilmu alam/ilmu pasti) mendominasi ilmu pengetahuan, dan pendekatan positivistik dalam sains diadopsi dalam ilmu-ilmu sosial untuk mengangkat ilmu-ilmu sosial "sederajat" dengan ilmu alam/eksakta.

Mengikuti cara pandang sains (juga ilmu sosial) dengan pendekatan positivismenya, menurut Donny Danardono (dalam Sulistyowati Irianto, 2008: 5), penganut positivisme hukum berpandangan, kepastian hukum akan tercapai bila hukum secara objektif mengidentifikasi, melegitimasi, dan mengubah hak-hak sosial dalam masyarakat menjadi hak-hak hukum. Hukum akan mewujudkan hal itu jika hukum mampu menerapkan metode terukur yang bebas dari subjektivitas. Itulah mengapa salah satu doktrin utama positivisme hukum adalah soal netralitas dan objektivitas hukum.

Netralitas dan objektivitas hukum hanya akan terwujud bila hukum bersifat tertutup dan otonom dari berbagai perspektif moral, agama, filsafat, politik, sejarah dan bahkan jenis kelamin. Hukum tidak berbicara mengenai baikburuk atau adil-tidak adil. Jika sebuah hukum masih berlaku, meski ia dinilai tidak adil, tetap harus dilaksanakan. Pemikiran ini fundamental bagi konstruksi pemikiran hukum. Ini alasan pokok kenapa para lawyers menerima begitu saja versi resmi undang-undang sebagai realitas legal dan cenderung tidak mempertanyakan hakikat dan tujuan utama hukum, serta menerima undang-undang atau hukum sebagai sesuatu yang given (Ngaire Naffine, 1997: 302).

Dalam pandangan para positivis, kepastian hukum merupakan hal penting dalam penerapan hukum. Semakin netral sebuah hukum, maka semakin tinggi kepastian hukum. Kepastian hukum tersebut dipaksakan oleh negara sebab hukum dibuat oleh lembaga yang memiliki otoritas sesuai dengan sistem hukum negara (command of law giver). Di samping karena dibuat oleh lembaga yang memiliki otoritas, kepastian hukum juga dapat diwujudkan dengan kerjasama antara hukum dengan berbagai sains positif-dalam hal ini ilmu alam/eksakta dan ilmu sosial yang menggunakan cara kerja ilmu alam/eksakta — untuk melegitimasi setiap perilaku masyarakat (Lloyd, 1973: 106-107).

Netralitas dan objektivitas inilah yang mendapat kritik keras dari para pemikir teori hukum feminis (feminist jurisprudencelfeminist legal theory). Para pemikir aliran feminis sejak akhir tahun 1960-an hingga sepanjang tahun 1970-an mendiskusikan mengenai kemungkinan mewujudkan hukum yang berdimensi kesetaraan jender, sebab netralitas dan objektivitas hukum secara konseptual telah menempatkan perempuan sebagai potential victims, dan secara aktual dalam banyak bidang dan keadaan sering mendiskriminasi perempuan karena kondisi khusus yang dialaminya, seperti menstruasi, hamil, dan sebagainya.

Perjuangan mula-mula feminis untuk merespon berbagai diskriminasi hukum yaitu melalui perjuangan hak yang berbeda dengan hak laki-laki karena perbedaan biologis dan fisiologisnya. Pemberian hak yang berbeda berupa perlakuan setara (equal treatment) atau perlakuan istimewa (special treatment) —yang belakangan kita kenal sebagai 
tindakan afirmatif (affirmative action). Perlakuan setara didasarkan pada cara pandang liberalisme bahwa setiap individu memiliki kedudukan yang sederajat. Beberapa keadaan khusus yang dialami oleh perempuan, menurut cara pandang perlakuan setara liberalis ini, juga dialami oleh lakilaki, seperti hak cuti perempuan karena hamil atau melahirkan bisa disetarakan dengan hak cuti laki-laki karena dia sakit. Itu berbeda dengan penganut tindakan afirmatif yang memandang bahwa laki-laki dan perempuan berbeda secara biologis dan fisiologis. Keadaan menstruasi dan hamil, misalnya, merupakan keadaan khusus yang berbeda secara biologis dengan laki-laki, karenanya perempuan harus mendapat tindakan afirmatif karena keadaan khususnya itu (Donny Danardono, 2008: 10-11).

Oleh feminis seperti Lucinda M Finley, dua cara pandang tersebut baik equal treatment maupun special treatment sama-sama tidak memadai dalam konteks masyarakat majemuk. Sebab keduanya menempatkan perempuan dengan berbagai keadaan khususnya sebagai titik berangkat merespon situasi diskriminatif terhadap perempuan. Jadi, perempuan dalam relasi dengan laki-laki ditempatkan sebagai the other, different, bahkan sebagai ancaman dan seterusnya. Keduanya ditempatkan dalam oposisi biner, posisi dua pihak yang saling bertentangan. Maka dua tindakan, baik setara maupun afirmatif, diandaikan akan mengasimilasikan perbedaan tersebut. Padahal masalah sesungguhnya adalah soal setting ruang yang sangat patriarkis. Pembedaan dan pendefinisian ruang privat dan ruang publik seringkali menjadi masalah sesungguhnya yang menyebabkan perempuan berada dalam situasi terdiskriminasi. Ruang privat dimana perempuan banyak bergelut dengannya dianggap sebagai sektor yang terpisah dan bahkan dianggap lebih rendah dari publik. Dengan demikian, memperjuangkan dua tindakan setara dan istimewa tanpa mempersoalkan ruang yang bias gender sesungguhnya berarti mendukung sistem hukum yang patriarkis (Lucinda $\mathrm{M}$ Finley, dalam D. Kelly Weisberg, 1993: 190-207).

Cara pandang yang menempatkan perempuan sebagai identitas yang relatif homogen merupakan cara pandang essensialisme. Penganut esensialisme menempatkan satusatunya musuh perempuan adalah patriarki. Padahal homogenisasi identitas perempuan sama bermasalahnya dengan patriarki. Idealnya, memandang perempuan harus sesuai dengan pengalaman kediriannya masing-masing yang heterogen. Oleh karena itu, hukum feminis harus didasarkan pada pengalaman perempuan tersebut (Patricia Cain, 1993: 359). Antiessensialisme membayangkan perempuan sebagai identitas yang beragam. Musuh perempuan, selain patriarki, juga konseptualisasi dan pendefinisian ruang; privat dan publik, dan posisi perempuan di dalamnya (Hillaire A Barnett, 1998: 57-67). Tindakan afirmatif atau egaliter dalam hukum menurut penganut anti essensialis tidak cukup. Essensialisme dalam teori hukum feminis berarti mengkonseptualisasi hukum baru yang tidak jauh berbeda dengan hukum positif patriarkis yang mereka kritik: objektif dan netral (Martha Minow, 2008: 339-345)

Untuk mengakomodasi kelemahan masing-masing, maka teori hukum feminis menawarkan metode hermeneutik dan dekonstruksi. Menurut Carol Smart, secara lebih fundamental diperlukan, antara lain, redefinisi diri perempuan dengan hukum sebagai medium melalui hermeneutika (bukan semata deduktif, induktif, verifikasi, tapi berangkat dari pengalaman individual perempuan). Di samping itu diperlukan dekonstruksi, misal dalam bentuk redefinisi ruang publik dan privat bagi perempuan. Dipengaruhi oleh "diskursus'-nya Michael Foucault, menurut Smart dalam hukum ada kuasa. Hukum menurutnya, sama dengan 
pengetahuan, yang di dalamnya ada kuasa untuk mendiskualifikasi kebenaran-kebenaran lain. Sementara hukum secara inkonsisten dapat mengadopsi pertimbangan non hukum dan menyimpangi logika internal dan tertutup hukum yang didoktrinkan positivisme hukum (Carol Smart, 1989: 4-14; Carol Smart dalam Hillaire A Barnett, 1998: 81-84), karenanya sistem hukum "baru" memungkinkan setiap perempuan dapat mendefinisikan diri mereka masing-masing. Di samping itu, pengungkapan pengalamanpengalaman personal perempuan harus dilakukan sebagai bentuk peningkatan kesadaran perempuan dan pembuatan pengetahuan baru (Patricia Cain, dalam D. Kelly Weisberg, 2008: 244-246).

Apabila diskursus feminist jurisprudence
dikontekstualisasikan dengan implementasi CEDAW di Indonesia, berbagai UU yang dibahas dalam bagian sebelumnya pada artikel ini merupakan hukum positif. Namun muatan dalam hukum tersebut bertentangan dengan doktrin positivisme hukum, dan sebaliknya mengarah kepada perwujudan preposisi feminist legal theory. Dua doktrin utama positivisme hukum adalah netralitas dan objektivitas hukum yang keduanya diidealkan sebagai prasyarat terwujudnya kepastian hukum. Dengan adanya keberpihakan hukum khusus kepada jenis kelamin tertentu, maka sesungguhnya hukum tidak netral, karena memiliki keberpihakan khusus (parsial) atas dasar pertimbangan jenis kelamin.

Dengan demikian dapat dikatakan, politik hukum di balik berbagai UU di muka menyimpang dari beberapa doktrin utama hukum positif tentang objektivitas dan netralitas hukum. Politik hukum di balik undang-undang tersebut mengarah kepada konstruksi teori hukum feminis (feminist jurisprudence). Konstruksi hukum dalam UU tersebut mengandung pengakuan dan tindakan keberpihakan khusus (affirmative actions) untuk peningkatan kualitas hidup, human security, dan partisipasi politik perempuan dalam berbagai infrastruktur dan suprastruktur politik serta dalam organisasi penyelenggara Pemilu.

\section{Kelemahan Implementasi Konvensi Anti Diskriminasi terhadap Perempuan dalam Politik Hukum Indonesia}

Konstruksi hukum tindakan afirmatif di Indonesia sangat lemah dan rapuh. Kerapuhan tersebut dapat diidentifikasi dari beberapa aspek: Pertama, dari aspek materi hukum, banyak regulasi di dalam undang-undang yang konstruksi logisnya belum sepenuhnya utuh, sehingga dalam banyak hal terkesan ngoyo woro tapi juga bisa dimaknai ketidakseriusan pembelaan atas perempuan. Misalnya, kuota partisipasi politik perempuan, dimana angka $30 \%$ yang disebut dalam Paket Undang-Undang Politik melahirkan beberapa pertanyaan lanjutan: mengapa $30 \%$ ? Mengapa tidak $50 \%$ ? Sehingga mendorong partisipasi tinggi seperti di Swedia yang mencapai hingga angka 48\% (Laporan Inter-Parliamentary Union, Institutional Change: Gender-sensitive Parliaments (chapter 5), 2008.). Di samping itu, dalam beberapa pasal punya kelemahan semantik soal partisipasi politik perempuan, misalnya, frasa yang digunakan oleh UU adalah "memperhatikan keterwakilan perempuan sekurang-kurangnya..."

Kedua, dari aspek aparat penegak hukum, dalam beberapa peraturan perundangan "feminis" masih ada ketidakjelasan siapa yang harus menegakkan peraturan tersebut. Beberapa undangundang tidak memberikan kewenangan yang nyata kepada lembaga mana yang harus spesifik menangani bila terjadi pelanggaran atas peraturan mengenai tindakan afirmatif.

Ketiga, tidak ada sanksi dan implikasi dari beberapa peraturan. Yang mencolok misalnya atas kuota 30\% partisipasi politik perempuan. Dalam konteks tersebut, partai politik dan KPU telah melanggar hukum dengan tidak terpenuhinya kuota 30\% sebagaimana ditekankan dalam Undang-Undang, namun tak ada sanksi apa pun atas mereka. Partai politik telah gagal memenuhi amanat hukum untuk pemenuhan kuota perempuan dalam kepengurusan mereka, khususnya di tingkat pusat, namun tidak ada sanksi apa pun atas itu. 
Hal itu menunjukkan bahwa konstruksi hukum dengan warna feminisme yang pekat tidak serta merta menjamin peningkatan partisipasi politik perempuan secara substantif, bahkan dalam tingkatan tertentu kontradiktif bagi penghormatan perempuan. Situasi ini semakin menunjukkan terwujudnya kekahawatiran-kekhawatiran beberapa kelompok feminis kritis yang berkeyakinan bahwa peraturan perundang-undangan bukanlah jawaban satu-satunya untuk soal diskriminasi terhadap perempuan.

Dengan demikian, dari tataran regulasi itu sendiri masih banyak yang harus diperbaiki. Pembenahan-pembenahan atas konten peraturan perundang-undangan merupakan keniscayaan. Hal itu untuk memastikan bahwa regulasi perlindungan perempuan dan penghapusan diskriminasi terhadap perempuan dapat diupayakan optimal.

\section{SIMPULAN}

Dari pembahasan terdahulu dapat disimpulkan beberapa hal berikut: Pertama, ratifikasi Konvensi Anti Diskriminasi Perempuan mengharuskan pemerintah Indonesia mengimplementasikannya secara lebih rinci melalui peraturan undang-undangan di bawah UU. Implementasi tersebut sudah mulai dilaksanakan secara parsial melalui beberapa peraturan perundang-undangan, antara lain UU Kesehatan, UU Pemberantasan Tindak Pidana Perdagangan Orang, UU Paket Politik (yang terdiri dari UU Pemilihan Umum DPR, DPD, dan DPRD, UU Pemilihan Presiden, UU Partai Politik, dan UU Penyelenggara Pemilihan Umum).

Implementasi Konvensi tersebut berimplikasi pada dua kecenderungan. 1) munculnya kecenderungan politik afirmatif bagi perempuan dalam berbagai bidang. Perempuan ditempatkan sebagai identitas yang membutuhkan pengakuan khusus atau istimewa secara formal dibandingkan dengan laki-laki, 2) mencoloknya warna aliran hukum feminis dalam hukum positif. Hukum positif merupakan turunan dari filsafat positivism hukum (legal positivism) yang mendoktrinkan netralitas dan objektivitas hukum demi terciptanya kepastian hukum. Dengan berbagai implementasi Konvensi tersebut dalam beberapa peraturan perundang-undangan, sangat menonjol warna hukum yang berpihak pada perbendaan gender sebagaimana didoktrinkan oleh aliran hukum feminis.

\section{DAFTAR PUSTAKA}

Abdul Hakim Garuda Nusantara. 1985. "Politik Hukum Nasional", makalah pada Kerja Latihan Bantuan Hukum. Surabaya: LBH Surabaya

Ani Widyani Soetjipto. 2005. Politik Perempuan Bukan Gerhana. Jakarta: Kompas

Budiardjo, Miriam. 1996. Dasar-Dasar Ilmu Politik. Jakarta: Gramedia

Cain, Patricia. 1993. "Feminism and Limits of Equality", dalam Weisberg, D Kelly, (ed.). 1993. Feminist Legal Theory: Foundations. Philadelphia: Temple University Press

Cain, Patricia. 1993. "Feminist Jurisprudence: Grounding the theories" dalam Weisberg, D Kelly, (ed.). 1993. Feminist Legal Theory: Foundations. Philadelphia: Temple University Press

Ciciek Farha. 2000. Perkosaan terhadap Perempuan di Ruang Domestik dan Publik. Makalah dalam Seminar Nasional "Islam, Seksualitas dan Kekerasan terhadap Perempuan". Yogyakarta 27-29 Juli 2000.

Convention on the Elimination of all Forms of Discrimination Against Woman (Konvensi Penghapusan Segala Bentuk Diskriminasi terhadap Perempuan), diambil dari Modul Training HAM untuk Polisi PBHI Yogyakarta, tahun 2006. 
Danardono, Donny. 2008. "Teori Hukum Feminis: Menolak Netralitas Hukum, Merayakan Difference dan AntiEssensialisme" dalam Sulistyowati Irianto (ed.), Perempuan dan Hukum: menuju Hukum yang Berperspektif Kesetaraan dan Keadilan. Jakarta: Yayasan Obor Indonesia

Fatayat, edisi II/April, tahun 2002

Hillaire A Barnett, Introduction to Feminist Jurisprudence, London-Sidney, 1998, Martha Minow, "Feminist Reason: Getting it and Losing It" dalam Weisberg, D Kelly, (ed.). 1993. Feminist Legal Theory: Foundations. Philadelphia: Temple University Press

Kollman, Nathalie. Kekerasan terhadap Perempuan. Jakarta: YLKI dan Ford Foundation, 1998.

Kompas, edisi 17 Juli, tahun 2007

Koran Tempo, 1 Oktober 2009

KPU (2009) Statistik Anggota DPR 2009-2014 Hasil Pemilu Legislatif Perbandingan Perempuan Dan Laki-Laki. Diambil dari http://mediacenter.kpu.go.id pada tanggal 25 Oktober 2010

Laporan Inter-Parliamentary Union, Institutional Change: Gendersensitive Parliaments (chapter 5), 2008.

Laski, Harold J. 1947. The State in Theory and Practice.(New York: The Viking Press

LBH APIK. 2001. Women, Law, and Development (Hak Asasi Manusia Kaum Perempuan, Langkah demi Langkah). Terjemahan. Jakarta: LBH APIK

Lexy J. Moleong. 1998. Metodologi Penelitian Bidang Sosial. Yogyakarta: Gadjah Mada University Press

\section{Metodologi Penelitian Kualitatif} Bandung: PT Remaja Rosda Karya

Lloyd. 1973. The Idea of Law. Harmondsworth: Penguin Books

Lucinda M Finley. 1993. "Transcending Equality Theory: A Way Out of the Maternity and the Workplace Debate", dalam Weisberg, D Kelly, (ed.). 1993. Feminist Legal Theory: Foundations. Philadelphia: Temple University Press

Moh. Mahfud MD. 2006. Politik Hukum Di Indonesia. Jakarta: Pustaka LP3ES Indonesia

Naffine, Ngaire. 1997. "Law and The Sexes", dalam Barnett, A. Hilaire. 1997. Sourcebook of Feminist Jurisprudence. London-Sidney: Cavendish Publishing Limited

Pusat Komunikasi Kesehatan Berperspektif Jender. 1999. Buku saku: Stop Kekerasan Dalam Rumah Tangga. Jakarta: Pusat Komunikasi Kesehatan Berperspektif Jender.

Sayekti Pujosuwarno. 1992. Penulisan Usulan dan Laporan Penelitian Kualitatif. Yogyakarta: Lemlit IKIP Yogyakarta

Smart, Carol. 1989. Feminism and Power of Law. London: Routledge

1997. "Feminism and Power of Law", dalam Barnett, A. Hilaire. 1997. Sourcebook of Feminist Jurisprudence. London-Sidney: Cavendish Publishing Limited

Soetjipto, Ani, et.al. 2010. Pengarusutamaan Gender di Parlemen: Studi terhadap DPR dan DPD Periode 2004-2009. Jakarta: UNDP Indonesia

Sri Wiyanti Eddyono. 2004. Hak Asasi Perempuan dan Konvensi $C E D A W$. Jakarta: Lembaga Studi dan Advokasi Masyarakat 
Steiner, Henry J., dan Alston, Philip. 1996. International Human Rights in Context (Law, Politics, and Morals). Oxford: Clarendon Press

Suharsimi Arikunto. 2002. Prosedur Penelitian Suatu Pendekatan Praktek. Jakarta: PT Rineka Cipta

Undang-undang No 22 tahun 2007 tentang Penyelenggara Pemilihan Umum

Undang-Undang No. 10 tahun 2008 tentang Pemilihan Umum

Undang-Undang No. 2 tahun 1998 tentang Partai Politik

Universal Declaration of Human Rights (Deklarasi Universal Hak Asasi Manusia), diambil dari Modul Training HAM untuk Polisi PBHI Yogyakarta, tahun 2006

\section{PENGARUH PENGASUHAN DAN PENGETAHUAN ORANGTUA TENTANG NAPZA TERHADAP PERILAKU RELAPSE ANAK}

\author{
Oleh: \\ Sri Weni Utami, Hetti Rahmawati, \& \\ Rias Gesang Kinanti \\ Universitas Negeri Malang
}

\begin{abstract}
Abstrak
Peran orangtua penting dalam menanggulangi penyalahgunaan NAPZA remaja dan upaya pencegahan kekambuhan (relapse prevention) karena orangtua adalah subsistem sentral pengendali sebuah keluarga dengan anak-anak di dalamnya. Sehingga orangtua memerlukan kesempatan belajar ketrampilan dalam hal mengurangi risiko perilaku relapse anak. Parent Support Training sebagai salah satu alternatif edukasi bagi orangtua remaja penyalahguna NAPZA untuk belajar dan berlatih tentang: pengetahuan tentang NAPZA, adiksi, pencegahan perilaku relapse dan dimensi pengasuhan efektif serta belajar rencana tindakan.

Untuk mencapai tujuan tersebut dilakukan survei awal penjajakan untuk menguji pengaruh pola pengasuhan orangtua (variabel bebas) dan pengetahuan orangtua tentang NAPZA (variabel bebas) terhadap perilaku relapse anak kembali menyalahounakan NAPZA (sebagai variabel tergantung). Metode pengambilan data dengan metode angket, analisis data angket dengan analisis regresi. Data tambahan diperoleh dari analisis kebutuhan pelatihan parent support training tentang urgensi pelatihan, karakteristik, bahan dan strategi pelatihan dengan metode wawancara. Analisis deskriptif digunakan untuk mengolah hasil survei. Subjek penelitian terdiri dari 60 orangtua dari remaja penyalahguna NAPZA yang berada di kota Malang, Yogyakarta dan Bogor.

Hasil analisis regresi menyatakan bahwa ada hubungan negatif yang signifikan antara pola asuh orangtua dengan perilaku relapse anak ( $p$ value $<0,05$ ), pengetahuan orangtua tentang NAPZA tidak berpengaruh terhadap perilaku relapse subjek (p-value $>0,05$ ), secara bersama variabel pola asuh orangtua dan pengetahuan orangtua tentang NAPZA memberikan kontribusi sebesar 30,10\% terhadap perilaku relapse anak $\left(R^{2}\right.$
\end{abstract}

